\title{
Dəm qazının toksik təsirinin diaqnostika və müalicəsi
}

t.ü.f.d., dosent Әfəndiyev İsmayll ${ }^{1}$, t.e.d., professor Şirəliyeva Rəna ${ }^{2}$, t.e.d. Məmmədbəyli Aytən ${ }^{2}$, t.ü.f.d. Oliyev Rahim ${ }^{2}$, t.ü.f.d. Seyidov Nabil ${ }^{1}$, Fətullayeva Leyla ${ }^{1}$

${ }^{1}$ Azari Toksikolqlarinın Darnayi

${ }^{2}$ Nevroloqların Milli Assosiasiyast

Taqdim edilib: 20 dekabr 2018-ci il.

Dorc üçün qəbul edilib: 25 yanvar 2019-cu il.

Olaqə məlumatı: t.e.ü.f.d. Ofəndiyev İ.N(e-poçt: efendiyevi@gmail.com)

\begin{abstract}
Abstrakt.
Karbon monooksid (CO, dəm qazı) metanın yanması nəticəsində yaranan iysiz, dadsız, rəngsiz, q1cıqlandırıcı xüsusiyyətləri olmayan qazdır. Adətən CO-nun atmosferdə konsentrasiyası 0,001 faizdən aşağı olur, lakin şəhər ərazilərində və ya qapalı mühitlərdə bundan yüksək ola bilər. Oksigenlə müqayisədə CO hemoqlobinlə daha möhkəm birləşərək, karboksihemoqlobin əmələ gətirir $(\mathrm{COHb})$, nəticədə oksigenin nəqli və sərfinin zəifləməsi baş verir. CO həmçinin iltihab kaskadını sürətləndirir, bunun hesabına MSS-də lipidlərin peroksidləşməsi və gecikmiş nevroloji fəsadlara səbəb olur.

Yanğınla əlaqədar tüstü ilə nəfəs alma karbon monooksid (CO) zəhərlənmələrinin əsas hissəsini təşkil edir. Ehtiyatsızlıqdan, yanğınla əlaqəli olmayan CO zəhərlənmələri il ərzində təxminən 5-10 ölümə səbəb olur, ölümlə nəticələnən qəsdən törədilmiş CO zəhərlənmələrin sayı isə bundan iki dəfə artıqdır. Qəsdən törədilən zəhərlənmələr üęün ölüm göstəricisi ehtiyatsızlıq üzündən baş verən hadisələrlə müqayisədə yüksəkdir.

Qəsdən zəhərlənmələrdən fərqli olaraq, ehtiyatsızlıqdan baş verən zəhərlənmələr həm mövsümi, həm də regional variasiyalar nümayiş etdirir və daha çox soyuq iqlim şəraitində q1ş aylarında baş verir. Osasən gecikmiş neyrokoqnitiv pozğunluqlarla özünü göstərən xəstəlik vəziyyəti, ilkin stabilləşmədən sonra zərərçəkənlərin 40 faizə qədərində persistə edir.
\end{abstract}

Açar sözlər: dəm qazı, zəhərlənmə, karbon monooksid, karboksihemoqlobinemia

\section{Giriş.}

Karbon monooksid (CO, dəm qaz1) metanın yanması nəticəsində yaranan iysiz, dadsız, rəngsiz, qıcıqlandırıcı xüsusiyyətləri olmayan qazdır. Adətən CO-nun atmosferdə konsentrasiyası 0,001 faizdən aşağı olur, lakin şəhər ərazilərində və ya qapalı mühitlərdə bundan yüksək ola bilər. Oksigenlə müqayisədə $\mathrm{CO}$ hemoqlobinlə daha möhkəm birləşərək, karboksihemoqlobin əmələ gətirir $(\mathrm{COHb})$, nəticədə oksigenin nəqli və sərfinin zəifləməsi baş verir. CO həmçinin iltihab kaskadını sürətləndirir, bunun hesabına MSS-də lipidlərin peroksidləşməsi və gecikmiş nevroloji fəsadlara səbəb olur.

Yanğınla əlaqədar tüstü ilə nəfəs alma karbon monooksid (CO) zəhərlənmələrinin əsas hissəsini təşkil edir. Ehtiyatsızlıqdan, yanğınla əlaqəli olmayan $\mathrm{CO}$ zəhərlənmələri il ərzində təxminən 5-10 ölümə səbəb olur, ölümlə nəticələnən qəsdən törədilmiş $\mathrm{CO}$ zəhərlənmələrin sayı isə bundan iki dəfə artıqdır. Qəsdən törədilən zəhərlənmələr üçün ölüm göstəricisi ehtiyatsılıq üzündən baş verən hadisələrlə müqayisədə yüksəkdir.

Qəsdən zəhərlənmələrdən fərqli olaraq, ehtiyatsızlıqdan baş verən zəhərlənmələr həm mövsümi, həm də regional variasiyalar nümayiş etdirir və daha çox soyuq iqlim şəraitində q1ş aylarında baş verir. Đsasən gecikmiş neyrokoqnitiv pozğunluqlarla özünü göstərən xəstəlik vəziyyəti, ilkin stabilləşmədən sonra zərərçəkənlərin 40 faizə qədərində persistə edir.

İntoksikasiyanın klinik təzahürləri CO-in dozasından (nəfəsalınan havada qazın qatılığı) və təsir müddətindən asılıdır. Nəfəsalınan havada COin qatılığının artma sürəti (qatılıq qradienti) də əhəmiyyətli sayılır. CO-in havada yüksək qatılıq 
qradienti zəhərlənmənin klinik təzahürünün inkişafını sürətləndirir. Xüsusilə, CO-in seçici təsiri ən çox onun qanın hemoqlobini ilə qarşılıqlı təsir reaksiyasında, müxtəlif formalı ağır hipoksiyanın inkişafı ilə qeyd olunur. $\mathrm{Bu}$ fonda, xüsusən karboksihemoqlobinemiya nəticəsində MSS-nin strukturlarında oksigen çatışmazlığına yüksək həssaslıq aşkar edilir. Aparılan tədqiqatlarda qeyd olunur ki, karboksihemoqlobinemiyanın toksik effekti orqanizmin bütün funksiyalarında, eləcə də, MSS-də əks olunur.

\section{MSS-nin zədələnməsinin klinik təzahürləri \\ Zəhərlənmənin ilkin mərhələsində} psixosensor pozğunluqların üstünlüyü aşkar olunur. $\mathrm{HbCO} 38.00 \pm 1.82 \%$ səviyyədə olduqda huşun soporoz dəyişilməsi inkişaf edir.

Beyin kötüyü-beyincik pozğunluqları mioz (HbCO $37.33 \pm 5.36 \%$ ), göz almalarının üzən hərəkəti (HbCO $45.07 \pm 1.11 \%)$ və anizokariya ( $\mathrm{HbCO} 45.34 \pm 1.17 \%)$ şəklində təzahür edir. Artıq erkən mərhələdə hərəkətlərin koordinasiyon pozğulması - ataksiya ( $\mathrm{HbCO}$ $29.71 \pm 1.52 \%$ ), intoksikasiyanın hədsiz ağır formalarında - tonik qicolmalar ( $\mathrm{HbCO} 68.22 \pm$ $1.74 \%$ ) müəyyən olunur.

Piramid pozğunluqlar əzələ hipertonusu ( $\mathrm{HbCO} 47.33 \pm 7.31 \%)$, vətər reflekslərinin artmas1 və sahələrinin genişlənməsi, Babinski və Oppenheym simptomlarının əmələ gəlməsi ilə təzahür edirdi.

Karboksihemoqlobinemiya fonunda ağır intoksikasiya keçirən zərərçəkənlərin 50\%-dən çoxunda komatoz vəziyyətdən çıxarkən kobud neyropsixiki pozğunluqlar aşkar edilirdi. $\mathrm{Bu}$ pozğunluqlar üzvi mənşəli psixozlar üçün xarakter olan simptomlar: retroqrad amneziya (HbCO $56.50 \pm 11.5 \%)$, zaman vo mokanda dezorientasiya, təqib maniyası və hallüsinasiyalar ilə təzahür edirdi.

CO ilə zəhərlənmənin klinik şəklinin öyrənilməsi, sinir sisteminin müxtəlif hissələrinin toksik karboksihemoqlobinemiyanın təsirinə fərqli rezistentliyini və zəncirvari artan: psixiki təzahürlər - beyin qabığı və retikulyar formasiyanın tormozlanmasını - beyin kötüyü strukturlarının ləngiməsini təsdiq edir. Beləliklə, filogenetik baxımdan daha "qədim" sayılan beyin kötüyü karboksihemoqlobinemiya və hipoksiyaya “yeni” hesab edilən beyin yarımkürələri qabığından daha dözümlüdür.

\section{Diaqnostika \\ Klinik diaqnostika}

Anamnez, eləcə də, professional, bölmə 1.2də qeyd edilən karbon-monooksidin əmələ gəlməsi mümkün olan şəraitlərdə zərərçəkənin olmasını ifadə edir. Ev şəraitində - bu zərərçəkənin səhər vaxtlarında və ya istirahət günündən sonra tapılması, eləcə də, bütün ailə üzvlərində və ev heyvanları da daxil olmaqla xəstəliyin ağırlıq dərəcəsindən asılı olan eynitipli əlamətlərin aşkarlanmasıdır.

Bundan əlavə, sobaların, su qizdirıcıların, isidici cihazların və s. düzəldilməməsi və ya qeyridüzgün istismarı aşkar olunur.

Klinik şəkli bölmə 2-də təsvir edilənlərə uyğun gəlir və bu zaman CO ilə zəhərlənmə ehtimalını imkan verən aparıcı simptomokompleks zəhərlənmənin ağırlıq dərəcəsindən asılı olan MSSnin zədələnməsinin müxtəlif təzahürləri sayılır. $\mathrm{Bu}$ simptomlar patoqnomonik sayılmır, lakin yuxarıda qeyd edilən anamnez ilə birlikdə CO ilə zəhərlənməni düşünməyə imkan verir. Xəstəliyin inkişafının bəzi xüsusiyyətləri onların $\mathrm{CO}$ ilə zəhərlənmənin əlaqəsinin təsdiqi ola bilər.

Zəhərlənmənin ağırlığının artması ardıcıllığında aşağıdakı simptomokomplekslərə baxmaq lazımdir:

1) baş ağrısı, ürəkbulanma, dəri damarlarının genişlənməəsi (dərinin hiperemiyası), qusma, baş gicəllənmə və görmə aydınlığının zəifləməsi;

2) huşun alaqaranlaşması, bayılmalar, döş nahiyyəsində ağrı, zəiflik, taxikardiya, taxipnoe;

3) ürəkdöyünmə, aritmiya, arterial hipotenziya, miokard işemiyası, tənəffüs dayanması, qeyri-kardiogen ağciyər ödemi, q1colmalar və koma;

Huşun pozğunluğunun dərinliyinin ilkin qiymətləndirilməsində Qlazqo Şkalasının istifadəsi məqsədəuyğun sayılır. Bundan əlavə, neyropsixoloji test vo neyrovizualizasiyanın aparılması məqsədəuyğun sayılır ki, bu da CO-in mərkəzi sinir sisteminə təsirini qiymətləndirmək üçün vacib dəyər verir.

\section{Laborator diaqnostika}

\section{Kimyəvi-toksikoloji diaqnostika}

Karbon-monooksid ilə zəhərlənmənin əsas diaqnostikası qanda $\mathrm{HbCO}$-nin səviyyəsinin ümumi hemoqlobinə faizlə nisbətinin ölçülməsini ifadə edir. $\mathrm{Bu}$ testə karbon-monooksidin orqanizmo artıq 
yüklənməsinin daha dəqiq indikatoru kimi baxılır. Eyni zamanda, HbCO-nin səviyyəsinin zəhərlənmənin ağırlığı ilə uyğunluğu (klinik şəkilə əsasən) karbon-monooksidin mənimsənilməsinə və eliminasiyasına təsir edən çoxsaylı fizioloji amillər görə həmişə uyğun sayılmır. Karbon-monooksidin yarımxaricolma müddəti, yəni onun səviyyəsinin $50 \%$ azalmas təxminən 300 dəqiqə təşkil edir, bununla əlaqədar HbCO-nin miqdarını onun təsirindən sonra müəyyən bir zamanda ölçülməsi ekspozisiya faktını göstərəcək, eləcə də, tədqiqat zamanı faktiki səviyyəsini hansı ki, karbon-monooksid ilə təmasın bitməsi anından aşağı ola bilər. Bunu diaqnozun qoyulmasında, zəhərlənmənin ağırlığının qiymətləndirilməsində, gözlənilən ağırlaşmaları, məhkəmə-tibbi ekspertizanı nəzərə almaq lazımdır.

İlkin HbCO-nin səviyyəsinin hesablanması üçün qəbul zamanı karboksihemqlobinin səviyyəsini nəzərə alaraq, zəhərlənmə anından keçən vaxtı (saatla), eləcə də, normobarik oksigenoterapiyanın aparılması və ya aparılmamasında C.J. Clarketal. (1981) nomoqrammasından istifadə etmək olar (şəkil1).

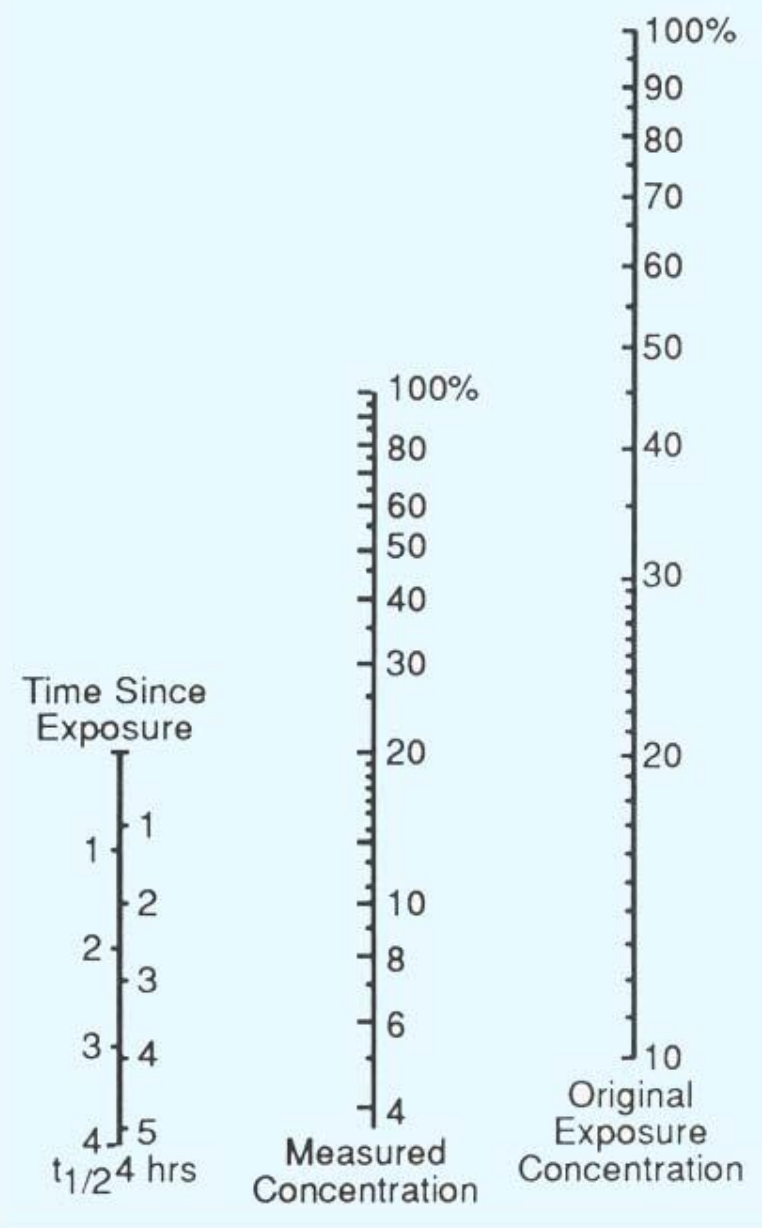

\section{Şəkil 1. Karboksihemoqlobinin ilkin qatılığının hesablanması üçün nomoqramma} (C.J. Clark et al., 1981)

$\mathrm{HbCO}$-nin ilkin səviyyəsinin (hadisə yerində) müəyyən edilməsi üçün xətkeşi hospitalizasiya zamanı təyin olunmuş $\mathrm{HbCO}$-nin səviyyəsinin şkalasından zəhərlənmə (oksigenterapiyasız və ya oksigen inhalyasiyası fonunda) anından keçən vaxt şkalasının üzərinə qoymaq lazımdır. Üçüncü şkalada onun ilkin səviyyəsi oxunulur.

Siqaret çəkməyənlərdə $\mathrm{HbCO}$-nin fizioloji səviyyəsi $<2 \%$ təşkil edir. HbCO-nin səviyyəsi $\geq$ $10 \%$ siqaret çəkdikdən dərhal sonra müşahidə etmək olar. Hesab edilir ki, HbCO-nin səviyyəsi $\geq 20 \%$ olduqda karbon-monooksid ilə zəhərlənmənin əlamətləri təzahür etməyə başlayır. Odəbiyyatlara əsaslanaraq, HbCO-nin 2-6\% diapazonda olmas1 ürək-damar xəstəliklərinin premorbid gedişatını, eləcə də, miokardın işemiyasını və ürək aritmiyalarının artmasını ağırlaşdırır. HbCO-nin $>50 \%$ səviyyə gətirib çıxaran karbon-monooksidin təsiri, bir qayda olaraq, hadisə yerində ölümlə nəticələnir.

HbCO-nin səviyyəsinin müəyyən edilməsi üçün hemoqlobinin fraksiyasını dəqiq ölçülməsinə imkan verən müasir TQM ABL tipli çoxdalğalı qaz analizatorlarından istifadə olunur. Bundan əlavə, spektrofotometriya, fotoelektrokolorimetriya metodu ilə də təyin etmək olar. Nəfəsverilən havada CO-in müəyyən edilməsi, xüsusən, indikator borularının istifadəsilə texniki təyin etmək mümkündür. $\mathrm{Bu}$ metod çox sadə və qatılığının $5 \mathrm{mq} / \mathrm{m}^{3}$-dən çox olduqda qiymətləndirilməsi üçün istifadə edilməsi mümkündür. Lakin, klinik praktikada bu tədqiqatın az informativ olması səbəbindən geniş yayılmamış və $\mathrm{HbCO}$-nin səviyyəsinin təyinindən geri qalır.

$\mathrm{HbCO}$-nin ilkin səviyyəsinin bilavasitə $\mathrm{CO}$ in təsir ocağında və ya zərərçəkəni hadisə yerindən dərhal evakuasiya etdikdən sonra müəyyən edilməsi daha informativ hesab etmək olardı. Buna görə də, laborator müayinə üçün flakonda vazelin yağı qatının altında və ya birdəfəlik şprizlərə qan yığılır. Lakin, bu yalnız xilasedən, ilk əlaqəli tibb və stasionar işçisi, HbCO-ni müəyyən etmək metoduna sahib olan arasında tam davamlılığın təmin edilməsi zamanı mümkündür.

Otaq havasinda CO-in müəyyən edilməsi diaqnostik dəyəri təşkil edə bilər, lakin, bir çox hallarda qazın əmələ gəlməsinin dayanması və otağın havalandırılmasından sonra bu mənasızdır. 
HbCO-nin təyinindən əlavə differensialdiaqnostik məqsədlə, həm klinik və bəzən məhkəmə-tibbi, eləcə də, inzibati və hüquqi aspektlər istehsalatda və fövqəladə hallarda zəhərlənmələr zamanı qanda və sidikdə etanolun olması və miqdarının tədqiqatı məqəsəduyğun olard1.

Bu məqsəd ilə daha etibarlı və həssas sayılan qaz və ya qaz-maye xromotoqrafiya üsulu istifadə olunur.

\section{Laborator molumatlarin interpretasiyasi,} $\mathrm{CO}$ ilo zohorlonmonin ağırlıq dorocosinin tosnifatı ilo klinik-toksikometrik yanaşma

a) Yüngül daracali zəhərlanma ( $\mathrm{HbCO}$ nin səviyyəsi $27,23 \pm 2,17 \%$ və yüksək) hadisə yerində huşun itməməsi ilə keçir, zərərçəkənlərdə psixosensor pozğunluqlar üstünlük təşkil edir (gicgahlarda vo ya halqavari lokalizasiyalı baş ağrılar, baş gicəllənmə, ürəkbulanma, qarında ağrı, zəiflik, yuxu pozğunluğu). Vəziyyət qənaətbəxşdir, nisbətən nəbzin və tənəffüsün artması, nisbi arterial hipertenziya olur. Baş ağrılarına şikayətlər $\mathrm{HbCO}-n$ in səviyyəsinin $27,77 \pm 1,72 \%$ olması zamanı, baş gicəllənmə $27,77 \pm 1,72 \%$, üşütmə $25,21 \pm 0,95 \%$, qulaqlarda küy $-11,59 \pm 0,09 \%$ olması zamanı qeyd olunur.

b) Orta ăğr daracali zahərlanma (HbCOnin səviyyəsi $30 \%$ və yüksək) q1sa müddətli huşun itməsi, stupor, baş vermiş hadisənin amneziyası, dezorientasiya, bəzən qicolmalar, inspirator təngnəfəslik, arterial hipertenziya, miokardın hipoksiyası, hərəkətlərin koordinasiyasının pozulması ilə xarakterizə olunur. Sütun-beyincik, piramid və ekstrapiramid simptomlar əmələ gəlir. Trofik dəyişiklər mümkündür. HbCO-nin qatılıq həddi $30,60 \pm 2,16 \%$-dən $38,20 \pm 1,81 \%$-ə kimi təşkil edə bilər.

c) Ăgır daracali zaharlanma (HbCO-nin səviyyəsi təxminən $50 \%$ ) komatoz vəziyyətlə, epileptikformalı qicolmalar, tənəffüsün və ürəkdamar fəaliyyətinin kəskin pozğunluğu ilə müşayiat olunur. Tez-tez trofik pozğunluqlar şəklində ağırlaşmalar, böyrək funksiyasının pozulması müşahidə olunur. HbCO-nin səviyyəsi $40 \%$-dan çox və müddətinin $3,23 \pm 0,70$ saat davam etməsi zamanı koma inkişaf edir, bu da zərərçəkənin həyatı üçün bilavasitə təhlükəliliyini göstərir. Ağır toksik komaların xarakterik xüsusiyyəti HbCO-nin səviyyəsinin 47,16 2 2,23\% olarkən hiporefleksiyanın və HbCO-nin $51,07 \pm 3,48 \%$ olması zamanı hipertermiyanın inkişaf etməsi sayılır. Ağır zəhərlənmə üçün xarakterik: artan beyin ödemi $\mathrm{HbCO} 53,53 \pm 5,87 \%$ zamanı və pis qarşısı alınan ağciyər ödemi (HbCO $55,93 \pm 4,19 \%$ ) sayılır.

d) Ölüm riskinin baş tutması HbCO-nin səviyyəsinin $60-70 \%$ olması zamanı, lakin $\mathrm{HbCO}$ nin səviyyəsinin $70 \%$-dən çox olması tez ölüm deməkdir.

\section{Klinik-biokimyəvi laborator diaqnostika.}

Ümumi qəbul olunmuş qanın, sidiyin klinik və biokimyəvi tədqiqatları diaqnostik əhəmiyyət daşımır, əsasən zəhərlənmənin ağırlıq dərəcəsini və inkişaf edən ağırlaşmaları göstərir. Buna baxmayaraq, orta ağır və ağır dərəcəli zəhərlənmə zamanı hioksiyaya, keçici hiperqlikemiyaya reaksiya kimi eritrositlərin sayının, eləcə də hemoqlobinin artması qeyd oluna bilər. TQM-nin tədqiqatı zamanı kompensator taxipnoe nəticəsində nisbi tənəffüs alkalozu və növbəti olaraq tənəffüs və ya qarışıq asidoz inkişaf edə bilər.

Miokardın hipoksik zədələnməsinin təsdiqi kimi troponin testinin məqsədəuyğun aparılması və dəm qazı ilə zəhərlənmə nəticəsində ürək ölümü riskinin qiymətləndirilməsi; pozision travmanın əlamətlərinin aşkarlanması zamanı: rabdomiolizin təyini və ya təsdiqi məqsədi ilə KFK-nın aktivliyinin nəzarəti; $\mathrm{Bu}$ məqsəd ilə qanda və sidikdə mioqlobinin tədqiqi, əsasən huşun itirilməsi ilə zəhərlənmə zamanı və pozision travmanın xarici əlamətlərinin olmasında lazımdır. $\mathrm{Bu}$ zaman böyrəklərin funksiyasının, endotoksikozun olması və səviyyəsinin klinik-biokimyəvi monitorinqi mütləq şəkildə aparılmalıdır.

\section{Instrumental vo funksional diaqnostika}

İnstrumental diaqnostik üsullar orqan vo sistemlərin zədələnməsinin ağırlığının qiymətləndirilməsinə və ağırlaşmaların aşkarına doğru yönlənmişdir.

a) karbon-monooksid ilə şərtlənmiş ürək zədələnmələrinin aşkarlanması məqsədi ilə EKQ-nın bütün xəstələrdə aparılması mütləqdir. $\mathrm{CO}$ ilə zəhərlənmə zamanı EKQ-da dəyişiklik qeyrispesifikdir, karbon-monooksid ilə intoksikasiya nəticəsində miokardın hipoksik dərəcəsini və koronar qan dövranı pozğunluğunu, miokardın 
işemiyası, kardiogen ağciyər ödemini və aritmiyanı göstərir.

Ağır hallarda EKQ-da miokard infarktındakı kimi lokal koronar qan dövranı pozğunluqları qeyd olunur. Göstərilən dəyişikliklər tranzitor xarakter daşıyır və intoksikasiyanın tez qarşısı alınanda və xəstənin ümumi vəziyyətinin yaxşılaşması zamanı itir. Ağır zəhərlənmələr zamanı, eləcə də, ürək nahiyyəsində (xüsusən, anamnezdə ürəyin işemik xəstəliyinin olması) ağrı şikayətlərinin olması təkrari müayinələrin aparılmasına göstərişdir.

b) Beynin funksional aktivliyinin pozulmasının diaqnostikası üçün, eləcə də, komanın differensial diaqnostikası məqsədilə elektroensefaloqrafiyadan (EEQ) istifadə olunur, bu zaman $\mathrm{CO}$ ilə zəhərlənmə üçün xarakterik dəyişikliklər - yüksəkvoltlu ləng aktivliyin üstünlüyü müşahidə oluna bilər, lakin EEQ-da normal bioelektrik aktivliyin bərpası klinik şəkildən geri qalır.

Baş beynin vəziyyətinin obyektiv qiymətləndirilməsi üçün kompyuter tomoqrafiyası üsulundan (KT) istifadə olunur. Ağır zəhərlənmənin ilk 12 saat anından $\mathrm{KT}$ və MRT zamanı solğun kürələr, bazal nüvələr və quyruqlu nüvə nahiyyəsində simmetrik sönmə aşkar oluna bilər. $\mathrm{Bu}$ dəyişikliklərin olması proqnostik pis əlamət sayılır. CO ilə zəhərlənmə zamanı bazal nüvələrin zədələnməsi MRT-da daha yaxşı aşkar olunur. Beynin ağ maddəsinin və mərkəzi nüvələrin zədələnməsi daha tez rast gəlinir. Bu dəyişikliklər zəhərlənmə anından 6 ay sonra da aşkarlanırdı. Bununla yanaşı, qeyd olunan diaqnostik üsullar CO ilə zəhərlənmənin dəqiq əlamətləri sayılmır və daha çox ağır keçirilmiş hipoksiyanı təsdiq edir. Bundan əlavə, kəskin zəhərlənmə və digər patoloji proseslərdə (kəllə-beyin travması, beyin qan dövranı pozğunluğu) anamnez CO ilə zəhərlənmə diaqnozunun qoyulmasinda kifayət qədər əsasların verilməməsi hallarında komanın differensial diaqnostikasina ehtiyac olduqda bu üsullardan istifadə olunur.

c) Digər funksional tədqiqatlar

Döş qəfəsi orqanlarının rentgenoqrafiyası kəskin toksik ağciyər ödeminin olmasını təsdiq etməyə imkan verir; pozision travma zamanı böyrəklərin USM-si məqsədəuyğundur.

\section{Müalicə}

\section{Spesifik farmakoterapiya}

Zəhərlənmənin spesik terapiyasının əsas göstərişi orqanizmdən CO-in maksimal tez xaric edilməsi və hemoqlobinin funksiyasının normallaşmasının bərpası üçün şərtlərin yaradılmasidir.

Zəhərlənmənin patogenezinə təsir edən və HbCO-nin əks dissosiasiyasına və oksihemoqlobinin əmələ gəlməsinə səbəb olan ümumi qəbulolunmuş antidot vasito oksigen sayılır. Hiperbarik oksigenasiya (HBO) daha effektiv sayilır. Bu da HbCO-nin dissosiasiyasını (10-15 dəfə) əhəmiyyətli artırmaqla plazmada sərbəst həll olan oksigenin miqdarını artırır.

Hiperbarik kamerada iş təzyiqi zəhərlənmənin ağırlıq dərəcəsinə uyğun olaraq təyin olunmalıdır: orta ağır zəhərlənmə zamanı təzyiq 0,60,9 atm., ağır dərəcəli zəhərlənmədə 1,0-1,5 atm.-ə bərabər olmalıdır. Seans zamanı barokamerada olarkən HbCO-nin qanda qatılı $\breve{g}_{1}$ 50\%-dən 20\%-ə kimi azalır. HBO seansının ümumi vaxtı $60-90$ dəqiqədən az olmayaraq, iş təzyiqinin platosunda kamerada olma vaxtı 30-60 dəqiqə təşkil edir.

Bir qayda olaraq, seansdan sonra xəstələrin vəziyyəti yaxşılaşır, huşu aydınlaşır, arterial təzyiq aşağ 1 düşür, nəbz və tənəffüs tezliyi stabilləşir, digər göstəricilər, əsasən, TQM və EKQ yaxşılaşır. Đgər HBO-nın bir saatlıq seansında patoloji simptomatika yox olmursa, onda hipoksik zədələnmə və beyin ödemi barəsində düşünmək lazımdır. Zəhərlənmənin ağır hallarında HBO seansını sutkada 4 dəfəyə qədər aparmaq olar.

CO ilə ağır zəhərlənmələr zamanı tənəffüs pozğunluğu olan xəstələrdə $\mathrm{HBO}$ reanimasyon barokamerada aparılır.

Hamilalarda CO ila zaharlanma zamanı $\mathrm{HBO}$ ilə müalicənin aparılmasıanada zəhərlənmənin ağırlıq dərəcəsindən asılı olmayaraq, dölün qanının CO-ə daha yüksək uyğunluğunu, plasentar baryerin keçiriciliyinin yaxşı olmasını və dölün qanında HbCO-nin səviyyəsinin ananın qanındakı ilə müqayisədə yüksək olmasını nəzərə alaraq (orta $15 \%$ ), bütün hallarda məsləhət görülür.

CO ilə kəskin zəhərlənmənin müalicəsi üçün nəzərdə tutulan spesifik vasitə kimi son illərdə Bis(1-vinilimidazol) sinkdiasetat (Asizol) istifado olunur. Bu preparat oksihemoqlobinin daha effektiv dissosiyasiyasına səbəb olur, hemoqlobinin oksigenə uyğunluğunu artırır və eyni zamanda, hemoqlobinin karbon-monooksidə nisbi uyğunluğunu azaldır və hüceyrələrin hipoksiyaya davamlılığını artırır. 
Asizol 1 saat ərzində qanda HbCO-nin ilkin qatılığını 2 dəfə azaldır, bu da nəfəsalınan adi hava ilə müqayisədə onun yarımparçalanma dövrünü 5,3 dəfə azaldır. Asizolun spesifik təsirindən əlavə qanda ortamolekulyar oliqopeptidlərin, limfositlərin, sidik cövhərinin, kreatininin miqdarına, transaminazaların aktivliyinə müsbət təsir göstərir və antiradikal aktivliyə malikdir. Asizol 6\%-11 sulu məhlul formasında əzələdaxilinə $1 \mathrm{ml}$ dozada yeridilir və ilkin tibbi-sanitar yardım mərhələsindən başlayaraq, zərərçəkənin $\mathrm{CO}$ olan ocaqdan praktik evakuasiyasından dərhal sonra, ardınca stasionarda asizol 2-3 saat intervalı ilə qandan CO tam çıxana kimi təkrar yeridilir. Ağır zəhərlənmələrin reabilitasiya dövründə asizol ilə müalicə yuxarıda qeyd edilən qeyri-spesifik təsirləri nəzərə alaraq davam etdirilir. Göstərilən sxemdə asizolun istifadəsi verilən zəhərlənmədə letallığı 1,9 dəfə azaltmağa imkan verir.

Müalicədən əlavə, asizol profilaktik vasitə kimi FHN-nin əməkdaşları, yanğın ocağında iş zamanı yanğınsöndürənlər tərəfindən istifadə oluna bilər. Preparatın yanğın ocağında işləməzdən 20-30 dəqiqə əvvəl 120 mq kapsulada peroral qəbul olunması məsləhət görülür.

\section{Simptomatik terapiya}

Simptomatik terapiyaya ilkin tibbi-sanitar yardım mərhələsində başlamaq lazımdır. Osas tədbirlər ilk növbədə xarici tənəffüsün adekvat bərpasına, yəni, yuxarı tənəffüs yollarının sərbəst keçiriciliyinə və adekvat oksigenlə təminatına yönəldilməlidir.

Növbəti mərhələdə isə beyin ödeminin profilaktikası və müalicəsi (sidik cövhərinin, furosemidin, onurğa beyinin punksiyas, kranioserebral hipotermiya), TQM-nin korreksiyas1, pnevmoniyanın profilaktikası (antibiotiklər, heparin), orqanizmin energetik tələbatının ödənilməsi (12 V insulin ilə 2 litrə qədər 5-10\%-li qlükoza məhlulu və $\mathrm{B}_{1}, \mathrm{~B}_{6}, \mathrm{C}$ vitaminləri), miorenal sindromun profilaktikası və müalicəsi üzrə tədbirlər aparılır.

$\mathrm{CO}$ ilə zəhərlənmənin somatogen mərhələsində toksik ensefalopatiyanın inkişafi zamanı HBO-nın qoruyucu rejimdə (0,3-0,5 atm.) günaşırı 60-80 dəqiqə 30 seansa qədər təkrar aparılması məsləhət görülür. Endotoksikozun olması zamanı müalicə $\mathrm{PF}, \mathrm{HS}$, HDF və ultrabənövşəyi fiziohemoterapiya (UBFHT) ilə birlikdə endotoksikozun qarşısı alınana qədər aparılır.

$\begin{array}{rrr}\text { Reabilitasiya dövründə } & \begin{array}{r}\text { nervpatoloqun, } \\ \text { psixiatrın, müalicə } \\ \text { idman tərbiyəsinin, }\end{array}\end{array}$ fizioterapiyanın müşayiəti məsləhət görülür.

Dərin koma inkişaf edən, tənəffüs və hemodinamika pozğunluğu uzun müddət saxlanılan və müalicəyə rezistent olan xəstələrdə somatogen mərhələdə HBO-dan effekt - şübhəlidir.

Metabolik asidozun inkişafı zamanı bufer laktat və natrium hidrokarbonat məhlulları göstərişdir. Natrium hidrokarbonat məhlulun dozası TQM-nə əsasən hesablanılır.

Yadda saxlamaq lazımdir ki, sərbəst tənəffüsü olan xəstələrdə $\mathrm{HCO}_{3}-1 n$ sürətli korreksiyası reflektor ağciyər ventilyasiyasının azalması və tənəffüsün ləngiməsi, metabolik alkalozun inkişafının ola bilməsi ilə müşayiət oluna bilər.

Bununla əlaqədar antioksidant xüsusiyyətli askorbin turşusu bərpaedici və bir sira metabolik proseslərin kofermenti kimi məlumdur və karbonmonooksid ilə zəhərlənmə zamanı $5 \mathrm{ml}$-dən $20 \mathrm{ml}$-ə qədər 5\%-li vitamin $\mathrm{C}$ məhlulunun 5\%-li qlükoza məhlulunda damcı şəklində və $10-30 \mathrm{ml}-ə$ qədər 2\%-li novokain məhlulunun yeridilməsi göstərişdir.

İnfuzion terapiyanın seçimi zamanı köçürülən məhlulların osmolyarlığını nəzərə almaq lazımdir.

İntensiv terapiyanın aparılması zamanı mütləq yadda saxlamaq lazımdır ki, beyin hüceyrələrinin stabil yüksək osmolyarlığı zamanı hüceyrəxarici sahənin osmolyarlı̆̆ının sürətli azalması mayenin hüceyrə daxilinə keçməsinə və onların ödeminə səbəb ola bilər. Diffuz sitotoksik beyin ödemi zamanı letallıq 90\%-ə çata bilər.

Keçirilmiş CO ilə zəhərlənmədən sonra hipovolemiya kəskin qan dövranı çatışmazlığın əsas səbəbi say1lır və onun kristalloidlər, $3: 1$ nisbətində qanəvəzedicilər ilə korreksiyası mütləqdir. ÜQDnın korreksiyası zamanı tək hemik hipoksiya ilə yox, həm də sirkulyator hipoksiya ilə mübarizə aparılır və bu zaman hemotokritin səviyyəsi $35 \%$ sərhədində saxlanılmalıdır. Köçürülən və çıxarılan mayenin balansına, itirilmiş elektrolitlərin və suyun elektrolit məhlullar ilə bərpa edilməsinə ciddi nəzarət etmək, qlükoza məhlulunun $(5 \%$ - 400-800 $\mathrm{ml})$ tiamin bromid, piridoksin ilə istifadəsi lazımdır.

Oyanıqlığın və q1colmaların qarşısı diazepamın - 2,0-4,0 $\mathrm{ml}$ 0,9\%-li natrium xlorid məhlulunda $\mathrm{v} / \mathrm{d}$, beyin ödeminin müalicəsi isə - 
dehidratasion terapiyanın, kranioserebral hipotermiyanın, kortikosteroidlərin istifadəsi ilə aparilır.

Müalicə ardıcıl və davamlı olmalıdır. Bütün metabolik təsirli maddələr günün birinci yarısında, vazoaktiv preparatlar isə sutka orzində bərabər yeridilir. Somatogen pozulmaların baş verməsi zamanı əvəzedici infuzion terapiya xəbərdaredici xarakter daşımalıdır.

Traxeobronxial ağacın yanı̆̆ı zamanı sanasion traxeobronxoskopiya; qurtlağın stenozunda is - traxeostomiya; ağciyər ödeminin müalicəsi (sidik cövhərin, laziksin, prednizolonun, maqnezium sulfatın yeridilməsi), pnevmoniyanın, infeksion ağırlaşmaların müalicəsi (antibiotikoterapiya) aparılır.

Miorenal sindromun, nefropatiyanın müalicəsi adi sxemlə (qələviləşdirmə, böyrək qan dövranının yaxşılaşdırılması, hemodializ və s.) aparilır.

MSS-nin karbon-monooksid zəhərlənməsi ilə müşayiət olunan hipoksik pozğunluqlarının korreksiyası üçün neyroprotektiv terapiya göstərişdir. Meqlumin natrium suksinatın (reamberin), inozin + nikotinamid + riboflavin + kəhraba turşusu (sitoflavin) və s. preparatların uğurlu istifadəsi barəsində məlumatlar vardır.

"Sitoflavin" preparatı - metabolik serebro- və sitoprotektor, hüceyrələrdə enerji əmələ gəlməni yaxşılaşdırma, toxumalar tərəfindən oksigenin utilizasiya proseslərini optimallaşdırmaq, antioksidant mühafizəli fermentlərin aktivliyini, hüceyrədaxili zülalların sitezini bərpa etmək, qlükozanın utilizasiyasını, piy turşuların və qamma-aminoyağ turşusunun resintezini artırmaq xüsusiyyətinə malikdir. Preparat $20 \mathrm{ml}-ə$ qədər sutkaliq dozada 200-400 $\mathrm{ml} 5-10 \%$-li qlükoza və ya $0,9 \%$-li natrium xlorid məhlullarında yeridilir və yaxud $10 \mathrm{ml}$ inyeksiya üçün su məhlulunda həll etməklə çox asta şəkildə bolyusla sutkada iki dəfə 8-12 saatdan bir 10 gün ərzində yeridilir. Karbonmonooksid ilə orta ağır dərəcəli zəhərlənmələr zamanı xəstələrdə sitoflavinin istifadəsi zamanı hipoksik ensefalopatiya əlamətlərinin reduksiya müddətinin azalması müşahidə olunmuşdur.

Reabilitasiya dövründə nervpatoloqun, psixiatrın, MBT-nin, fizioterapevtin müşahidəsi məsləhət görülür.

CO ilə ağır zəhərlənmə keçirən şəxslərdə reabilitasiya 2 il ərzində davam edir, çünki, çox vaxt uzunmüddətli və davamlı periferik sinirlərin zədələnməsinin boyun-çiyin pleksiti növü üzrə mil, dirsək və ya orta sinirin zədələnməsi, eşitmə, görmə, oturaq və ya bud sinirlərinin polinevritlərinin prosesə cəlb olunması müşahidə olunur. Astenovegetativ sindromun, toksik ensefalopatiyanın, korsakov amnestik sindromun, psixi xəstəliklərin kəskinləşməsi və ya inkişafı mümkündür.

\section{Ușaqlarda zəhərlənmənin müalicəsi}

Uşaqlarda və böyüklərdə müalicə tədbirlərinin əsasl zərərçəkəni CO-in yüksək qatılığı olan sahədən çıxarılmasından başlayır. Növbəti mərhələdə spesifik və simptomatik terapiya aparilır.

Seansa başlamazdan əvvəl döş qəfəsinin rentgenoqrafiyası, TQM-nin göstəricilərinin təyini, ilkin EEQ və EKQ (seansdan sonra təkrar aparılır) aparılması məsləhət görülür. Zəhərlənmiş xəstələrin ağır vəziyyətini nəzərə alaraq, barokameralarda kompressiya və dekompressiya (10-15 dəq. ərzində) $0,1 \mathrm{~atm} /$ dəq. sürətlə təzyiq dəyişməsilə yavaş-yavaş aparılır. Xəstənin toksikogen mərhələdə müalicəvi təzyiq altında (1,0-2,5 atm.) qalma müddəti 40-50 dəqiqə, somatogen mərhələdə isə posthipoksik ensefalopatiyanın olması zamanı (0,3-0,5 atm.) 60100 dəqiqə edir.

Oyanıqlığın qarşısını almaq üçün uşaqlara benzodiazepin sirasından olan sedativ preparatlar təyin olunur.

HBO-nın istifadəsinə əks-göstəriș xəstələrdə ekzotoksik şokun dekompensator formasının inkişafı ilə əlaqəli hədsiz ağır vəziyyəti zamanı hemodinamikanın əsas göstəricilərinin korreksiyası üçün ilkin reanimasion tədbirlərin keçirilməsinin tələb edilməsi sayılır.

Asizol preparatı uşaqlarda rəsmi olaraq sınaqdan keçirilməyib, ona görə də, pediatrik praktikada istifadəsinə icazəsi yoxdur.

Simptomatik terapiya böyüklərdə olduğu kimi eyni əsaslı aparılır, yalnız, dərman maddəsinin yaşa görə dozası hesablanılır.

CO ilə kəskin zəhərlənmənin müalicəsinin ümumi sxemi şəkildə 2-də təsvir edilmişdir. 


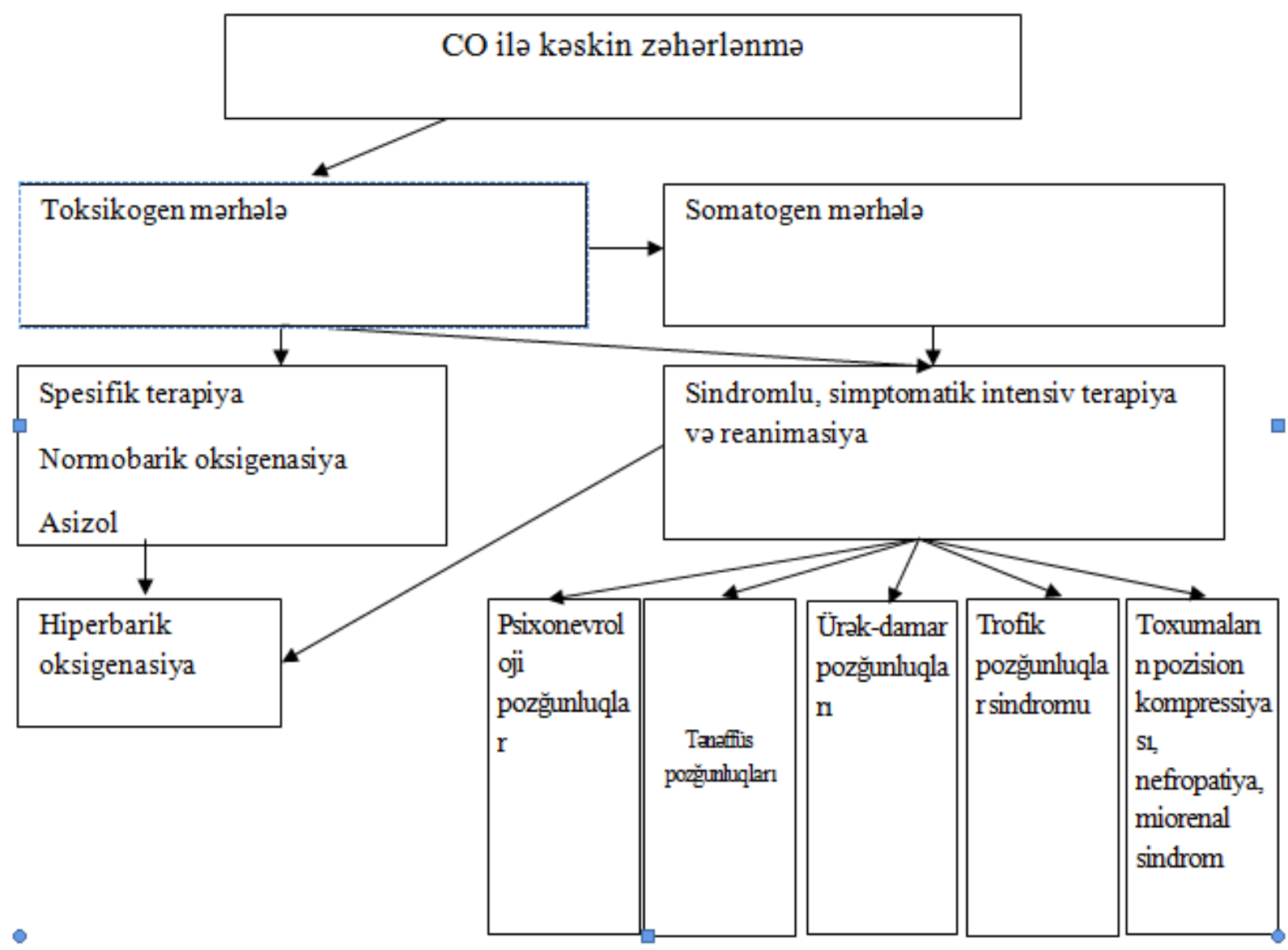




\section{IXTISSARLARIN SIYYAHISI}

\begin{tabular}{|l|l|l|}
\hline ALaT & - & Alaninaminotransferaza \\
\hline ASaT & - & Aspartataminotransferaza \\
\hline FTKM & - & Fövqəladə-təhlükəli kimyəvi maddələr \\
\hline HBO & - & Hiperbarik oksigenasiya \\
\hline HDF & - & Hemodiafiltrasiya \\
\hline QMX & - & Qaz-maye xromatoqrafiyası \\
\hline HS & - & Hemosorbsiya \\
\hline KT & - & Kompyuter tomoqrafiyası \\
\hline TQM & - & Turşu-qələvi müvazinəti \\
\hline KFK & - & Kreatinfosfokinaza \\
\hline LDH & - & Laktatdehidrogenaza \\
\hline MRT & - & Maqnit-rezonans tomoqrafiya \\
\hline DEQH & - & Dövr edən qanın həcmi \\
\hline MIVQ & - & Maksimum icazə verilən qatılıq \\
\hline PF & - & Plazmaferez \\
\hline USM & - & Ultrasəs müayinəsi \\
\hline UBHT & - & Ultrabənövşəyi hemoterapiya \\
\hline UBŞ & - & Ultrabənövşəyi şüalanma \\
\hline FBS & - & Fibrobronxoskopiya \\
\hline MSS & - & Mərkəzi sinir sistemi \\
\hline QF & - & Qələvi fosfataza \\
\hline EKQ & - & Elektrokardioqramma (kardioqrafiya) \\
\hline ETŞ & - & Ekzotoksik şok \\
\hline EEQ & - & Elektroensefaloqramma (ensefaloqrafiya) \\
\hline HbCO & - & Karboksihemoqlobin \\
\hline HbO & - & Oksihemoqlobin \\
\hline
\end{tabular}

Maliyyə Mənbəyi: Məqalənin hazırlanmasında heç bir kənar maliyyə mənbəyindən istifadə edilməyib.

Maraqların toqquşması: Qeyd edilməyib.

\section{ӘDӘBIYYYAT:}

1. Медицинская токсикология. Национальное руководство. Под ред. акад. Е. А. Лужникова - М.: ГЭОТАР-Медиа, 2014. $928 \mathrm{c}$.

2. Отравление монооксидом углерода (угарным газом) / Под ред. Ю. В. Зобнина / - СПб.: Издательство "Тактик-Студио", 2011. - 80 c.

3. Эфендиев И. Н., Максудов А. С. Организация помощи пострадавшим в результате массового отравления угарным газом и продуктами неполного сгорания на примере взрывов и пожаров в бакинском метрополитене. Вестник Российской военно-медицинской академии. 2005, № 1 (14), с. 242-243

4. Эфендиев И. Н., Азизов В. А. Эпидемиологические наблюдения случаев острых ингаляционных отравлений моноксидом углерода (угарным газом) в Азербайджане. Azərbaycan Təbabətin Müasir Naliyyətləri // 2009, N. 6, s. 98-101

5. Эфендиев И. Н. Клинический случай массового отравления угарным газом и продуктами горения во время пожара в жилом здании в Бинагадинском районе г. Баку 19 мая 2015 года. Биомедицина. 2017, N. 3, s. $87-91$

6. Ozizov V. Ә., Ofəndiyev İ. N., Maqsudov A. S. Kliniki Toksikologiya. Dərs vəsaiti. Bakı: Azərbaycan Tibb Universiteti. $284 \mathrm{~s}$.

7. Rose JJ, Wang L, Xu Q, McTiernan CF, Shiva S, Tejero J, Gladwin MT. Carbon Monoxide 
Poisoning: Pathogenesis, Management, and Future Directions of Therapy. Am J Respir Crit Care Med. 2017 Mar 1;195(5):596-606. doi:10.1164/rccm.201606-1275CI.

8. Macnow TE, Waltzman ML. Carbon Monoxide Poisoning In Children: Diagnosis AndManagement In The Emergency Department. Pediatr Emerg Med Pract. 2016 Sep;13(9):1-24.

9. Wu PE, Juurlink DN. Carbon monoxide poisoning. CMAJ. 2014 May 13;186(8):611. doi: 10.1503/cmaj.130972.

10. American College of Emergency Physicians Clinical Policies Subcommittee (Writing Committee) on Carbon Monoxide Poisoning:, Wolf SJ, Maloney GE, Shih RD, Shy BD, Brown MD. Clinical Policy: Critical Issues in the Evaluation andManagement of Adult Patients Presenting to the Emergency Department With Acute Carbon Monoxide Poisoning. Ann Emerg Med. 2017 Jan;69(1):98-107

11. Weaver LK. Clinical practice. Carbon monoxide poisoning. N Engl J Med. 2009 Mar 19;360(12):1217-25. doi: 10.1056/NEJMcp0808891.

12. Chan MY, Au TTs, Leung KS, Yan WW. Acute carbon monoxide poisoning in a regional hospital in Hong Kong: historical cohort study. Hong Kong Med J. 2016 Feb;22(1):46-55. doi: 10.12809/hkmj144529

13. Betterman K, Patel S. Neurologic complications of carbon monoxide intoxication. Handb Clin Neurol. 2014;120:971-9. doi: 10.1016/B978-0-70204087-0.00064-4.

14. Dubrey SW, Chehab O, Ghonim S. Carbon monoxide poisoning: an ancient and frequent cause of accidental death. Br J Hosp Med (Lond). $2015 \quad$ Mar;76(3):159-62. doi: 10.12968/hmed.2015.76.3.159.

15. Hampson NB, Piantadosi CA, Thom SR, Weaver LK. Practice recommendations in the diagnosis, management, and prevention of carbon monoxide poisoning. Am J Respir Crit Care Med. 2012 Dec 1;186(11):1095-101. doi: 10.1164/rccm.201207-1284CI

16. Bleecker ML. Carbon monoxide intoxication. Handb Clin Neurol. 2015;131:191-203. doi: 10.1016/B978-0-444-62627-1.00024-X.

17. Clinical Guidance for Carbon Monoxide (CO) Poisoning After a Disaster. https://www.cdc.gov/disasters/co_guidance.ht $\mathrm{ml}$

18. https://www.uptodate.com/contents/carbonmonoxide-poisoning 